DOI: $10.15575 /$ kt.v1i1.7124

\title{
Perjuangan KH.Choer Affandi Pendiri Pesantren Miftahul Huda Manonjaya
}

\author{
Dian Prayoga \\ UIN Sunan Gunung Djati Bandung, Indonesia \\ Email: Diangg@gmail.com
}

\begin{abstract}
Miftahul Huda Islamic Boarding School established by the late K.H. Choir Affandi and is the largest Salafiyah Pesantren in the Tasikmalaya Regency, which still maintains the Salafiyah system by slightly adapting the learning system of the Modern Islamic Boarding School so that this results in a level of progress in the field of education for the students themselves. This pesantren was born thanks to the patience and the desire and obedience of the founder of his teacher. Using a qualitative approach by conducting a face-to-face study and obtaining data through interviews, literature studies and direct field spaciousness. The development of pesantren can also be said to be developing rapidly, and this is evidenced by the wider boarding school area, although not as a whole building the boarding school, but the vast ownership of pesantren land proves that the boarding school can be independent and develop without depending on the helping hand of benefactors, this vast area of pesantren land reached 8.5 hectares with an area of 5 hectares in buildings and houses as well as boarding schools, while the rest were made into agricultural land, animal husbandry, fish ponds. With the total number of santri reaching 2,085 people.
\end{abstract}

Keywords: KH.Choer Affandi; Pesantrent Miftahul Huda; Tasikmalaya.

\begin{abstract}
Abstrak
Pesantren Miftahul Huda yang didirikan oleh Almarhum K.H. Choer Affandi, dan merupakan Pesantren Salafiyah terbesar yang berada di wilayah Kabupaten Tasikmalaya, yang masih mempertahankan sistem Salafiyah dengan sedikit mengadopsi sistem pembelajaran dari Pesantren Modern sehingga dengan hal ini mengakibatkan tingkat kemajuan dalam bidang pendidikan bagi santrinya itu sendiri. Pesantren ini lahir berkat kesabaran dan keinginan serta kepatuhan pendiri terhadap gurunya. Menggunakan pendekatan kualitatif dengan melakukan studi serajah dan cara mendapatkan data dilakukan dengan wawancara,studi literature dan turun langsung kelapangan. Perkembangan pesantren juga bisa dikatakan berkembang dengan pesat, ini terbukti dengan luas pesantren yang semakin luas walaupun tidak secara keseluruhan dijadikan bangunan pesantren namun kepemilikan lahan pesantren yang luas membuktikan pesantren tersebut bisa mandiri dan berkembang tanpa tergantung dari uluran tangan dermawan-dermawan, luas lahan pesantren ini mencapai 8,5 Ha dengan luas 5 Ha di tempai bangunan dan rumah serta asrama pesantren, sedangkan sisanya dijadiakan lahan pertanian, peternakan, kolam ikan. Dengan jumlah santri secara keseluruhan mencapai 2.085 jiwa.
\end{abstract}

Kata Kunci: KH.Choer Affandi; Pesantrent Miftahul Huda; Tasikmalaya.

\section{PENDAHULUAN}

Keberadaan pondok pesantren sebagai basis penyebaran agama dan tempat mencari ilmu Agama Islam di Indonesia sudah berjalan berabad-abad lamanya, dan secara pasti tidak diketahui kapan pertama kali keberadaan pesantren dan pola pendidikan macam ini dimulai di Indonesia. "Namun demikian, beberapa penelitian telah menduga bahwa benih-benih kemunculan pondok pesantren sebagai pusat penyebaran dakwah sekaligus sebagai tempat untuk mempelajari lebih dalam tentang ilmu Agama Islam sudah ada jauh sejak keberadaan para Wali Sanga, yaitu sekitar abad ke 15"(Haedari, 2004).

* Corresponding author

Received: September 01, 2019; Revised: October 19, 2019; Accepted: December 26, 2019 
Khazanah Theologia, Vol. 1 No. 1: 7-22

Perjuangan Kh.Choer Affandi Pendiri Pesantren Miftahul Huda Manonjaya

Dian Prayoga

Istilah pondok pesantren menunjukan dua istilah yang merujuk pada satu pengertian. Pesantren pada dasarnya adalah tempat belajar para santri, sedangkan pondok berarti rumah atau tempat tinggal sederhana. Secara garis besar pengertian pondok pesantren adalah suatu lembaga pendidikan atau pengajaran yang mengajarkan Agama Islam dan mempunyai ciri-ciri tertentu antara lain: Adanya Pondok (asrama), Mesjid, Santri, Pengajaran kitab-kitab klasik, dan Kyai sebagai pengasuh dan pengajar. Selain dari pondok pesantren, satu hal yang identik dengan pesantren adalah santri, untuk itu penulis perlu menjelaskan tentang pengertian dari kata santri itu sendiri. Kata Santri menurut Nurcholis Majid dalam "Bilik-Bilik Pesantren" (Madjid, 1997) merupakan kata yang berasal dari kata Shastri (Bahasa Sansakerta) yang berarti Melek Huruf, sedangkan dalam bahasa Jawa, kata Santri berasal dari kata Cantrik yang berarti orang yang selalu mengikuti seorang guru kemanapun guru itu menetap. Ada dua istilah santri dalam istilah santri itu sendiri untuk masyarakat Jawa yaitu, Santri Mukim dan Santri Kalong. Santri Mukim adalah murid-murid yang berasal dari daerah jauh dan menetap di pondok pesantren, sedangkan untuk Santri Kalong adalah murid-murid yang berasal dari daerah sekitar pesantren itu berada, dan mereka melakukan aktifitas pembelajaran pada waktu-waktu tertentu saja. Bagian yang tidak kalah penting dalam pondok pesantren adalah Kyai sebagai pengasuh atau pengajar di pesantren, dan Kitab Kuning sebagai bahan pelajaran utama di Pondok Pesantren.

Menurut Martin Van Bruinnesen (www.kabar-pendidikan.blogspot. com). Kyai merupakan unsur kunci dalam pesantren, karena itu sikap hormat (takzim) dan kepatuhan mutlak terkadap Kyai merupakan salah satu nilai pertama yang ditanamkan kepada santri. Daud Rasyid (www.Kabarpendidikan.blogspot. com). Mengatakan kyai dan santri akan berinteraksi secara terus menerus dan lama dipesantren sehingga kegiatan santri dapat dievaluasi dan dibentuk oleh kyai, kyai dengan "karomahnya" adalah orang yang senantiasa memahami keagungan Alloh SWT dan rahasia alam. Dalam Kamus Besar Bahasa Indonesia, Istilah karomah berasal dari bahasa Arab, secara bahasa berarti mulia, karomah dapat diartikan suci dan dapat mengadakan sesuatu diluar kemampuan manusia biasa karena ketaqwaanya kepada Tuhan. Dengan demikian, kyai dianggap memiliki kedudukan yang tidak terjangkau, utamanya oleh orang biasa. Selain itu Kitab Kuning pada umumnya dipahami sebagai kitab-kitab keagamaan yang berbahasa Arab, menggunakan aksara Arab yang dihasilkan oleh ulama dan pemikir muslim lainnya pada masa lampau. Menurut Mahmud dalam "Model-Model Pembelajaran di Pesantren" (2006: 11). Kitab Kuning mempunyai format sendiri yang khas dan warna kertas yang kekuningkuningan.

Berkaitan dengan hal tersebut diatas, salah satu daerah yang terkenal dengan sebutan Kota Santri untuk wilayah Jawa Barat adalah Tasikmalaya, di wilayah Kabupaten Tasikmalaya inilah banyak terdapat pesantren-pesantren yang menjadi basis penyebaran Agama Islam dan pangkal pusat Dakwah Islamiyah. Salah satu pesantren besar di wilayah Kabupaten Tasikmalaya adalah Pesantren Miftahul Huda yang berada di daerah Manonjaya, yang terletak di sebelah utara alun-alun Manonjaya tepatnya berada di Kampung Pasir Panjang Desa Kali Manggis Kecamatan Manonjaya Kabupaten Tasikmalaya.

Pesantren Miftahul Huda tersebut didirikan pada tanggal 7 Agustus 1967 oleh Alm.K.H. Choer Affandi yang berasal dari Kampung Palumbungan Desa Cigugur Kecamatan Ciamis. Pada awalnya beliau datang beserta putra pertamanya yaitu K.H. Abdul Fattah yang merangkap sebagai asistennya ke wilayah Manonjaya tepatnya kedaerah Cisitu Kidul dengan alasan karena adanya tiga orang Santri yang pernah mengaji (alumni) di Pesantren Wanasuka (Pesantren yang didirikannya di daerah Cigugur), disana Almarhum mendirikan Pesantren Gombongsari Cisitu Kidul (sekarang dilanjutkan oleh murid pertama almarhum, yaitu Ajengan Otoh dengan nama Pesantren Pusaka Gombongsari), kemudian beberapa bulan kemudian almarhum pindah ke daerah Manonjaya dengan menempati tanah wakaf seluas $11.200 \mathrm{~m}^{2}$ atau 
Khazanah Theologia, Vol. 1 No. 1: 7-22

Perjuangan Kh.Choer Affandi Pendiri Pesantren Miftahul Huda Manonjaya

Dian Prayoga

200 Bata dan sebagian tanahnya lagi dibeli dengan harga Rp.350/ bata dari almarhumah Hj.Mardhiyah, yaitu saudagar kaya di wilayah tersebut (Abdul Fattah: 2010: 9), disanalah bangunan pertama Pesantren Miftahul Huda dibangun.

Sisi menarik dari pembahasan ini adalah ketidak tahuan masyarakat sekitar mengenai latar belakang berdirinya pesantren ini yang jelas mempunyai andil besar dalam memajukan bidang Pendidikan Islam untuk wilayah Tasikmalaya khususnya daerah Manonjaya, padahal disatu sisi Pesantern Mifahul Huda adalah pesantren besar dengan jumlah santri yang cukup banyak, sampai dengan sekarang santrinya berjumlah kurang lebih 2.085 santri. Selain itu Pesantren Miftahul Huda sendiri banyak menciptakan kader dalam penyebaran Islam melalui dakwah, sehingga terkenal alumni dari pesantren tersebut banyak yang menjadi pendakwah terkemuka seperti halnya K. H. Abdullah Gymnastiar (Aa Gym).

\section{METODE PENELITIAN}

Metodologi penelitian perlu ditetapkan berdasarkan sifat masalah, kegunaan, dan hasil yang hendak dicapai (Moleong, 2011). Mengingat topik permasalahan yang akan diteliti merupakan rentetan peristiwa yang terjadi dimasa lampau, maka pendekatan metode yang dipakai dalam penelitian ini adalah menggunakan penelitian sejarah. Selain dari pada itu metode penelitian yang digunakan adalah observasi dan wawancara (Rahardjo, 2010). Dengan pendekatan kualitatif (Sugiyono, 2013),

\section{HASIL DAN PEMBAHASAN}

\section{Latar Belakang Berdirinya Pesantren Miftahul Huda Manonjaya}

Suatu hal yang mustahil apa bila seseorang dapat memberikan penilaian yang objektif pada seorang pelaku sejarah, jika tidak mengetahui latar belakang atau biografi pelaku sejarah, dasar pemikirannya, serta cita-citanya. Pada kesempatan ini, penulis mencoba membahas akan hal ini diharapkan supaya semua pembaca dapat mengetahui siapa dan bagaimana pelaku sejarah membela dan membangkitkan sesuatu yang patut diketahui dan dikenang. Pesantren Miftahul Huda tidak berdiri begitu saja, melainkan ada sosok sentral didalamnya yang dengan giat dan kerja keras serta sifat rendah diri yang berusaha membanguan dari awal hingga menghasilkan suatu lembaga pendidikan Pondok Pesantren yang besar seperti sekarang ini. Untuk itu penulis mencoba menjelaskan sedikit tentang pendiri Pondok Pesantren Miftahul Huda Manonjaya.

\section{Biografi Pendiri Pondok Pesantren Miftahul Huda}

Hampir secara keseluruhan masyarakat luas telah mengetahui jika pendiri awal Pesantren Miftahul Huda adalah K.H. Choer Affandi atau yang akrab disebut Uwa Ajengan, dimana sebutan Uwa Ajengan adalah sebutan yang berlaku bagi pendiri Pesantren Miftahul Huda yang pertama saja. Dalam Bahasa Sunda kata "Uwa"berarti kakak dari ayah atau ibu, sedangkan kata "Ajengan" berarti orang yang dipandang mempunyai ilmu agama yang melebihi masyarakat secara umum, dan biasanya mempunyai pengajian dengan skala besar atau kecil. Namun tidak jarang masih banyak masyarakat yang tidak mengetahui akan latar belakang atau biografi K.H. Choer Affandi. Untuk itu perlulah kiranya penulis membahas sedikit tentang biografi K.H. Choer Affandi.

K.H. Choer Affandi lahir pada hari Senin tanggal 12 September 1923 M di Kampung Palumbungan Desa Cigugur Kecamatan Cigugur Kabupaten Ciamis. Beliau merupakan anak dari pasangan Raden Mas Abdullah bin Hasan Ruba'i yang masih mempunyai keturunan Raja Mataram dengan Siti Aminah Binti Marhalan yang mempunyai keturunan dari Wali Godog Garut. K.H Choer Affandi merupakan anak kedua 
Khazanah Theologia, Vol. 1 No. 1: 7-22

Perjuangan Kh.Choer Affandi Pendiri Pesantren Miftahul Huda Manonjaya

dari tiga bersaudara, beliau mempunyai kakak yang bernama Husein (Darajat), dan seorang adik perempuan yang bernama Husnah (Emih).

Menurut K.H Abdul Fattah pada tanggal 22 Januari 2012 pukul 10.00 WIB, sewaktu peneliti mengunjungi rumahnya yang berada di kompleks Pesantren Miftahul Huda, beliau mengatakan: "Dalam darah Onong Husen mengalir darah bangsawan dan darah ulama yang dominan dalam membentuk kepribadian K.H. Choer Affandi, hal ini terbukti dengan sikap Uwa yang sangat tertarik pada ilmu-ilmu agama dan ilmu pengetahuan umum. Pada umumnya kepribadian anak akan terbentuk oleh pribadi orang tua, begitu juga dengan K.H Choer Affandi yang dibesarkan oleh sang ayah yang menjadi bangsawan".

Selanjutnya K.H Abdul Fattah menambahakan: "Jika Pada waktu itu ayah K.H. Choer Affandi adalah pegawai Belanda. Hal itu menjadi kekhawatiran tersendiri bagi neneknya yang bernama Haesusi terhadap K.H. Choer Affandi, sehingga setelah Onong Husen menamatkan pendidikan umum yaitu HIS atau Hollandsch Inlandsche School, maka pada tahun 1936 M neneknya membujuk Onong atau Choer Affandi untuk mengaji di Pesantren K.H Abdul Hamid, disana Onong Husen belajar mengaji selama kurun waktu enam bulan. Kemudian beliau pulang ke Cigugur dan mengaji di Pesantren Cipancur Cigugur. Selesai dari sana, Onong Husen pergi mengaji kembali ke daerah Sukamanah Tepatnya Beliau mengaji di Pesantren K.H Z. Mustofa (Pahlawan Nasional)", kemudian K.H. Abdul Fattah berhenti sejenak bercerita: "berapa lama Onong mengaji Saya tidak terlalu mengetahui, tutur K.H Abdul Fattah menambahkan lagi".

Sejenak pembicaraan kami tergangu dengan kedatangan salah satu anggota keluarga K.H. Abdul Fattah yang mengajak beliau untuk segera pergi guna menghadiri pengajian Bulananya di luar pesantren, namun K.H abdul Fattah masih memberikan kesempatan kepada penulis untuk bisa lebih lama bersamanya dan mewawancarainya. K.H. Abdul Fattah melanjutkan ceritanya." Sewaktu Onong mengaji di Pesantren Sukamanah beliau diikut sertakan sebagai santri yang diharuskan ikut terhadap seorang santri senior yang bernama $\mathrm{H}$. Masluh sebagai santrinya, H. Masluh adalah santri yang dimukimkan atau sudah mendapat restu dari K.H. Zainal Mustofa untuk membuka pesantren, maka dengan segala kepatuhan dan ketaatan beliau terhadap sang guru, berangkatlan Onong beserta rombongan mengikuti $\mathrm{H}$. Masluh. Pesantren baru yang dibuka oleh H. Masluh bernama Pesantren Legok Ringgit dan di pesantren inilah Onong kecil mendaftarkan dirinya dengan nama Choer Affandi. Dimana Pesantren Legok Ringgit berjarak kurang lebih $500 \mathrm{M}$ dari pesantren Sukamanah ke sebelah timur"

K.H. Abdul Fattah juga menambahkan: "Choer Affandi atau Onong tumbuh menjadi santri yang begitu patuh dan taat terhadap guru, rajin belajar, serta mempunyai disiplin belajar yang tinggi. Hal ini terbukti pada awal pembukaan Pesantren Legok Ringgit, ketika itu terjadi wabah penyakit menular yang penyebarannya dibawa oleh tikus, sehingga pada waktu itu pemerintahan belanda melakukan berbagai cara guna menumpas penyebaran penyakit tersebut supaya tidak meluas, yaitu dengan cara merobohkan banguan rumah, tidak terkecuali dengan rumah $\mathrm{H}$. Masluh. Dikarenakan perobohan banguan rumah $\mathrm{H}$. Masluh dilakukan secara bertahap dan bagian dapur belur direnovasi yang mengakibatkan tikus-tikus itu bersarang disana, dan memenuhi bak mandi rumah H. Masluh. Melihat kejadian itu, maka beliau memanggil santrinya untuk membersihkan bak mandi itu, dan hanya Choer Affandi lah yang bersedia menguras air dan membuang bangkai tikus yang ada dalam bak mandi tersebut, tanpa menghiraukan dirinya terjangkit penyakit. Satu hal yang menjadi dasar Choer Affandi berani melakukan hal itu karena didalam dirinya tertanam sikap patuh atau takzim terhadap gurunya, sedangkan dari sikap Choer Affandi yang dikatakan rajin dan giat dalam belajar adalah Choer Affandi tidak pernah ketinggalan pembelajaran dan selalu bisa menamatkan talaran kitab-kitab yang ditugaskan gurunya jauh sebelum batas waktu yang ditentukan". 
Khazanah Theologia, Vol. 1 No. 1: 7-22

Perjuangan Kh.Choer Affandi Pendiri Pesantren Miftahul Huda Manonjaya

K.H. Abdul Fattah juga melanjutkan kembai ceritanya: " bahwa H. Masluh juga mengangkat Choer Affandi sebagai anaknya beserta santri lain seperti: Sadili dan Jahuri yang berasal dari Kerawang, Rois yang berasal dari Bogor, dan Ruhiyat yang berasal dari Tasikmalaya. Tidak hanya itu sikap ketakziman Choer Affandi juga terlihat ketika beliau diperintahkan untuk belajar mengaji di Pesantren Pani'is pimpinan K.H. Shobir pada tahun 1940 M yang berada di Desa Cigadog Leuwisari selama enam bulan untuk belajar Ilmu Ushul Fiqh, menurut Rohadi Abdul Fatah dalam Rekontruksi Pesantren Masa Depan (2005: 41) Ilmu Ushul Fiqh adalah ilmu yang membahas dasar-dasar dan metode untuk menarik (istinbath) sebuah hukum fiqih pada tataran tertentu adalah produk, prosesnya mencakup dalam ushul fiqh ini (Fatah, 2005). Tujuan dipelajarinya ilmu ini adalah supaya santri dapat mengetahui proses bagaimana sebuah hukum dihasilkan, dari sejak penetapan masalahnya. Setelah belajar di Pesantren Pani'is kemudian beliau pulang kembali ke Legok Ringgit. Setelah itu beliau diperintahkan juga untuk belajar mengaji di PesantrenTunagan dibawah pimpinan K.H. Dimyati yang berada Tasikmalaya tepatnya dekat bekas terminal Cilembang Tasikmalaya sekarang, guna mempelajari Ilmu Astronomi atau perbintangan yang ada pada kitab "Taqribul Maqshod". Dan pulang kembali ke pesantren Legok Ringgit. Sepulang dari pesantren tersebut tepatnya pada tahun 1941 M Choer Affandi kemudian di perintahkan untuk belajar mengaji tentang Ilmu Hisab atau Ilmu Falaq di Pesantren Jembatan Lima Jakarta pimpinan K.H. Mansur sampai bulan Desember 1941 M, dari Pesantren Jembatan Lima Choer Affandi tidak langsung pulang ke Pesantren Legok Ringgit melainkan berangkat ke Pesantren Gunung Puyuh di Sukabumi guna mempelajari Ilmu Faraid atau Ilmu Waris dan diteruskan ke Pesantren Tipar yang masih di Sukabumi Guna mempelajari Ilmu Tafsir. Perjalanan beliau dilakukan tidak terlepas dari perintah sang guru, sepulang dari Sukabumi tepatnya pada bulan Maret 1942 M, Choer Affandi meminta petimbangan H. Masluh untuk membuka Pesantren di daerah asalnya yaitu di Cigugur. Dan pada tahun itu juga Choer Affandi mendirikan Pesantren Wanasuka di daerah asalnya tersebut. Walaupun sudah menjadi pimpinan atau sudah mempunyai pesantren yang lumayan besar keinginan belajar dan mencari ilmu Agama yang lebih masih diperlihatkan oleh Choer Affandi dengan mengaji di Kyai Abdul Hamid dan K.H. Didi Abdul Majid, yang dilakukan seminggu sekali. sehingga dari ketekunan dan kepintaran yang beliau miliki hingga pada akhirnya beliau menjadi wakil kedua ulama tersebut dalam memberikan pelajaran kepada mustami yang menghadiri pengajian.

Keperibadian Uwa menurut Bapak Uho sewaktu penulis mewawancarainya. "Uwa itu sikapnya aneh, beliau seolah-olah bisa mengetahui apa yang akan terjadi, sampai pada suatu hari beliau berkata: "mang Uho, tingalikeun geura nyak, engke abi mah bakal boga pasantren anu santrina loba pisan, jeng jadi gudang na duit" perkataan itu ternyata sekarang terbukti bila kita melihat pesantren Miftaul Huda yang besar dengan jumlah santri yang begitu banyak serta kesejahteraan keluarga beliau pun terjamin".

Akhirnya segala sesuatu akan kembali pada sang pencipta, peribadi yang menjadi panutan para santri beserta masyarakat Manonjaya pun di panggil sang Khaliq pada bulan Nopember 1994, dan di kebumikan di Kompleks Pesantren Miftahul Huda. Innalillahi wa'ina illaihi roziun.

\section{Latar Belakang Kedatangan K.H Choer Affandi ke Manonjaya dan Mendirikan Pesantren Miftahul Huda}

Sebagaimana telah ketahui bersama, jika K.H. Choer Affandi adalah orang yang berasal dari Kampung Palumbungan Desa Cigugur Kabupaten Ciamis, dan pernah belajar mengaji diberbagai pesantren seputaran wilayah Tasikmalaya, Jakarta, dan Sukabumi. Namun jika melihat akan keberadaan Pesantren Miftahul Huda yang didirikan oleh beliau di wilayah Manonjaya sekarang, maka akan timbul 
Khazanah Theologia, Vol. 1 No. 1: 7-22

Perjuangan Kh.Choer Affandi Pendiri Pesantren Miftahul Huda Manonjaya

Dian Prayoga

suatu pertanyaan tentang apa yang menjadi latar belakang K.H Choer Affandi datang serta mendirikan Pesantren Miftahul Huda di daerah Manonjaya. Melihat permasalahan tersebut, maka dalam hal ini penulis merasa penting untuk mengungkap motif dibalik kedatangan Uwa Ajengan atau K.H, Choer Affandi ke wilayah Manonjaya. Untuk mengetahui hal tersebut penulis mendatangi salah seorang saksi hidup yang rumahnya pernah di tempati oleh K.H. Choer Affandi yaitu Bapak Uho Saepudin (80 thn) pada tanggal 23 Januari 2012 di daerah Babakan Sari Cisitu.

Menurut keterangan yang didapatkan penulis dari Bapak Uho Saepudin, K.H. Choer Affandi datang ke Manonjaya sekitar tahun 1963 M, beliau datang ke Manonjaya sebagai ulama besar yang sudah mempunyai banyak santri dan mempunyai pesantren terkemuka di Cigugur, K.H. Choer Affandi datang pertama kali kerumah Bapak Abad, dimana Bapak Abad adalah adik dari Istri beliau. Selain dari pada itu, kedatangan beliau ke sana di dorong karena wilayah Manonjaya merupakan daerah yang strategis dan dianggap daerah yang mempunyai jarak yang sama antara Bandung sebagai Provinsi Jawa Barat dengan daerah asalanya Cigugur. Selaian hal tersebut, alasan lainnya juga yang mendorong kedatangan K.H. Choer Affandi ke Manonjaya adalah karena di daerah Manonjaya ada tiga orang mustami atau orang yang sering mengikuti pengajian mingguan atau bulanan di Pesantren Wanasuka Cigugur, serta adanya petunjuk dari guru beliau yaitu K.H Didi Abdul Majid atau yang lebih dikenal dengan sebutan Agan Didi untuk pindah kedaerah Manojaya, jika Choer Affandi menginginkan ilmu yang manfaat dan mempunyai pesantren yang besar dan terkenal. Di Manonjaya Beliau tinggal di rumah Bapak Abad selama kurang lebih tiga bulan, kemudian pindah ke rumah Bapak Uho dikarenakan ada sesuatu hal yang terjadi diantara Istri beliau dengan salah satu keluarga Bapak Abad.

K.H. Choer Affandi kemudian tinggal di rumah Bapak Uho selama enam bulan, beliau sering mengajar ngaji masyarakat sekitar, dikarenakan K.H. Choer Affandi merupakan kyai besar dan dianggap berilmu agama yang tinggi, sehingga banyak orang yang berdatangan untuk bersilaturahmi dan meminta pendapat tentang masalah yang sedang dihadapi. Banyak yang merasakan manfaat dari apa yang K.H. Choer Affandi berikan sehingga ada salah satu orang yang bernama H. Bahrudin bersedia memberikan rumah kepada beliau di daerah Regol Manonjaya (sekarang dekat POM Bensin Manonjaya) setelah mendapatkan rumah hasil pemberian dari H. Bahrudin, kemudian beliau pindah ke daerah Cisitu Kaler, di sana beliau membuka Pesantren Gombong Sari untuk pengajian anak-anak dan warga sekitar (Fazari BA, 1996).

Selanjutnya pada tanggal 24 Januari 2012 Pukul 14.00 WIB, penulis mendatangi salah satu murid beliau sewaktu mendirikan tempat pengajian di Cisitu Kaler yang bernama Ajengan Otoh yang berusia 62 tahun. Menurut keterangan yang beliau ceritakan kepada penulis, yang menjadi latar belakang kedatangan Uwa Ajengan atau K.H. Choer Affandi ke manonjaya adalah karena dimanonjaya terdapat tiga mustami yang sering mengikuti pengajian mingguan dan bulanan di Pesantren Wanasuka Cigugur, secara keseluruhan apa yang dikemukakan oleh Bapak Uho sama dengan apa yang diceritakan oleh Ajengan Otoh, namun sedikti tambahan dari hasil wawancara penulis dengan beliau, kedatangan pertama kali Uwa Ajengan ke Manonjaya itu datang kerumah H. Pakih kemudian ke H. Jahidi, lalu ke Ajengan Onang dan terakhir tinggal di Ajengan Uho. Tinggal di sana selama kurang lebih dua tahun lalu pindah ke Cisitu Kaler setelah ada yang membuatkan rumah kepada Uwa Ajengan.

Salah satu keistimewaan Uwa Ajengan ketika datang atau pindah ke Cisitu Kaler adalah Sikap Uwa yang sangat dermawan dan rendah hati sehinggga masayarakat disana sangat mengagumi dan menghormati beliau. Adapun santri pertama Beliau yang mengaji di daerah Cisitu Kaler atau Pesantren Gombongsari hanya berjumlah 11 orang, dan satu orang putranya, mereka adalah:

a) Ajengan Otoh; 
b) K.H. Sajidin, Cisaga;

c) H. Hasan;

d) H. Badar, Margahayu;

e) H. Andang, Selakaso;

f) H. Ece, Selakaso;

g) H. Hudri, Alm;

h) H. Dayat, alm;

i) H. Oni, Miftahul Huda;

j) Ajengan Mumu Tarmudi, Manonjaya;

k) H. Khoer, kompleks Miftahul Huda,dan

l) K.H. Abdul Fattah, selaku putra beliau.

Setelah beberapa bulan mendirikan Pesantren Gombongsari di Cisitu Kaler jumlah santri semakin bertambah, bahkan pada waktu itu datang juga santri dari Cigugur seperti H. Soleh Nasihin dan dari Bojong Konang, serta H. Umar Nawawi. Selain itu juga datang pula santri-santri dari Parigi Ciamis, Cijulang Ciamis, Banjar Ciamis, dan Garut. Hingga pada akhirnya setelah enam tahun berada disana, Pesantren Gombongsari mempunyai santri berjumlah 350 santri yang terdiri dari laki-laki semua. Selain mengajar mengaji dan ilmu Kitab Kuning, serta Asma'ul Husna atau pengajaran menghapal untuk nama-nama Alloh SWT yang 99. Uwa Ajengan juga mendirikan pabrik mie dan sang istri yaitu Uwa Oyoh belajar berdagang pakaian dengan alasan supaya hidupnya tidak bergantung pada masyarakat dan mempunyai penghasilan sendiri. Selama enam tahun Uwa mengajar dipesantren tersebut dan kemudian pindah ke daerah Cihanyang yang sekarang menjadi Pesantren Pusat dari Miftahul Huda.

Namun, hal paling penting untuk latar belakang pendirian Pesantren Miftahul Huda yang sekarang berdiri menurut K.H Abdul Fattah adalah ketika Uwa Ajengan selalu mengisi pengajian di Mesjid Kaum Manonjaya setiap seminggu sekali dengan cara berjalan kaki. Anehnya, selama kurun waktu tiga minggu beliau selalu beristirahat disuatu tempat yang sama dan sering diserang rasa kantuk yang luar biasa, dan ketika tertidur selalu bermimpi akan hal yang sama pula, dimana beliau disarankan untuk membuat pesantren di tempat tersebut (Fattah, 2010). Disamping itu juga karena Pesantren Gombongsari terletak di tengah-tengah pemukiman penduduk sehingga sedikit mengganggu bila beliau ingin menerapkan sikap disiplin terhadap para santrinya. Setelah kejadian tersebut Uwa Ajengan berpikir bagaimana caranya untuk mendapatkan tanah tersebut, untuk dibanngun pesantren. Hingga pada suatu ketika sewaktu beliau mengisi pengajian di Mesjid Kaum Manonjaya, ternyata ada seorang mustaminya yang meninggal dunia, tanpa berpikir panjang lagi Uwa beserta jema'ah yang lain pergi ke rumah tersebut, pada waktu itu Uwa dipercaya untuk memimpin bacaan dan do'a-do'a. Uwa menjalankan apa yang keluarga almarhum minta dengan penuh hidmat dan penuh penghayatan sehingga membuat semua orang yang mendengarnya ikut menangis dan merinding dengan mendengar bacaan-bacaan ayat-ayat Alqur'an yang dibacakan oleh Uwa Ajengan. Setelah selesai pemakaman jenazah, Uwa dipanggil istri almarhum yaitu Hj. Mardiah, pada kesempatan itu Hj. Mardiah memberikan tanah wakaf seluas 100 bata, namun Uwa menolaknya dengan alasan terlalu sedikit untuk membuat pesantren yang besar, alhasil $\mathrm{Hj}$. Mardiah memutuskan supaya Uwa datang kembali keesokan harinya. Pada hari yang telah ditentukan Uwa datang kembali dan Alhamndullilah keluarga Hj. Mardiah bersedia memberikan tanah Wakaf seluas 200 bata, bahkan sebagian tanahnya bersedia dijual kepada Uwa dengan harag Rp. 150,- harga waktu itu walaupun dengan pembayaran secara kredit. Setelah resmi mendapatkan tanah tersebut, kemudian Uwa beserta masyarakat dan santrinya bergotong royong membuka lahan untuk dijadikan pesantren sekaligus membuat batu bata untuk bahan bangunan. 
Khazanah Theologia, Vol. 1 No. 1: 7-22

Perjuangan Kh.Choer Affandi Pendiri Pesantren Miftahul Huda Manonjaya Dian Prayoga

Dari hasil penerangan beberapa sumber maka dapat disimpulkan jika kedatangan Uwa Ajengan ke daerah Manonjaya adalah karena Beliau mengikuti anjuran yang diberikan oleh gurunya, selain karena adanya Mustami atau almuni yang pernah mengikuti pengajian di Pesantren Wanasuka.

\section{Perkembangan Pesantren Miftahul Huda Manonjaya Dari Awal Berdiri Sampai Sekarang}

Pesantren Miftahul Huda yang ada di daerah Manonjaya tidaklah lahir dan berdiri dengan langsung besar seperti sekarang ini, ada perjuangan dan pengabdian serta penggorbanan yang dilakukan oleh K.H Choer Affandi beserta masyarakat sekitar, dimana dalam kenyataanya Pesantren Miftahul Huda berkembang dari titik terkecil sampai bisa seperti sekarang ini. Berkaitan dengan hal tersebut maka penulis mencoba mengklasifikasikan tingkat perkembangan yang terjadi di Pondok Pesantren Miftahul Huda yang secara garis besar, penataan situasi diupayakan dalam empat pendekatan, yaitu:

a. Bangunan atau Sarana Prasaran yang ada atau Lingkungan Fisik

Lingkungan pendidikan yang paling pertama dan paling wajar adalah lingkungan keluarga. Seorang anak dilahirkan, dibesarkan, dan dibina dalam lingkungan keluarga sebelum dibina dalam lingkungan lain, karena itu lingkungan keluarga sangatlah besar pengaruhnya dalam perkembangan pendidikan anak. Menurut K.H. Abdul Fattah dalam hadits Rosululloh SAW, bersabda yang artinya kurang lebih "setiap yang dia lahirkan, ia lahir dalam keadaan suci, maka kedua orang tuanya yang akan mencemari kesucian itu menjadi Nasrani, Yahudi, dan Majusi" kandungan arti dari hadits di atas adalah lingkungan keluarga merupakan situasi tertentu, dimana kedua orang tua sangatlah dominan dalam pembinaan pribadi anak, sedangkan kematangan pribadi anak dapat dipengaruhi oleh situasi dimana anak itu dididik dan dibesarkan.

Sepanjang sejarahnya Pesantren Miftahul Huda belum pernah berhenti membangun, seringkali satu bangunan belum selesai maka sudah kembali membuat fundasi untuk bangunan selanjutnya, dengan catatan bangunan yang sebelumnya dibangun sudah bisa dipakai untuk kegiatan yang menunjang kegiatan-kegiatan yang ada di pesantren. Pada awal pendiriannya Pesantren Miftahul Huda membangun tujuh kamar atau kobong untuk para santrinya dan membuat madrasah dengan ukuran 30x8 $\mathrm{m}^{2}$, serta membuat rumah untuk tempat tinggal Uwa beserta keluarga, setelah beberapa tahun kemudian tempat tersebut berkembang menjadi pesantren yang cukup maju dengan santri yang selalu bertambah dari hari ke hari, hingga pada suatu hari ketika datang alumni pesantren Wanasuka tempat Uwa mengajar ilmu Agama pertama kali yaitu B. Ali Howas, beliau mengusulkan Kepada Uwa agar bisa menerima santri putri dengan alasan Ali Howas memiliki anak perempuan "Uwa atuh pami teu ka abotan mah kumaha upami nampi santri istri? Da geuning abdi ngagaduhan murangkalih istri, atuh apmi Uwa teu tiasa nampi santri istri anak abi moal tiasa janteun Ustadah". Maka atas dasar pemikiran tersebut Uwa mulai menerima santri putri sebagai anak didikannya di Pesantren Miftahul Huda. Santri putri pada waktu itu ditempatkan di bagian dapur rumah Uwa yang sering disebut Pondok Gayot, disebut Pondok Gayot adalah karena di bawahnya terdapat kolam ikan. Adapun santri putri yang pertama mengaji di sana adalah: Hj. Paridah Binti H. Nawawi yang berasal dari Jakarta, Ustad Muhayah, Hj. Rohani, Hj Fatimah.

Demikian dengan lingkungan yang terdapat di Pesantren Miftahul Huda, penataan lingkungan fisik sangat diperhitungkan dalam pembuatannya, hal ini dikarenakan latar belakang santri yang berasal dari berbagai daerah dan kalangan status sosial yang berbeda. Penataan letak bangunan yang berada di kompleks Pesantren Miftahul Huda mencerminkan suatu upaya kyai dalam mengkondisikan santri dengan lingkuangan fisik yang memungkinkan dapat terjalinnya komunikasi antara santri, kyai dan masyarakat dalam lingkungan tersebut. Salah satu contohnya terlihat dengan dari pembangunan mesjid yang mempunyai luas $100 \mathrm{~m} \mathrm{x} 50 \mathrm{~m}^{2}$ yang ditempatkan ditengah kompleks pesantren yang secara 
fsikologis telah memaksa santri agar selalu melaksanakan solat lima waktu secara berjama'ah, karena jarak mesjid dan asrama santri tidak terlalu jauh (Raharjo, 1985).

Menurut Ustad Aceng yang menjadi pengurus dalam bidang pembangunan di Pesantren Miftahul Huda sejak tahun 2000 sampai sekarang, beliau mengatakan: "Secara keseluruhan banguanan-banguanan yang dibanguan di Pesantren Miftahul Huda tidak dicatat atau dimuat dalam buku kesekertariatan, hal ini terjadi karena tidak adanya rasa kepemilikan perorangan dari para keluarga pendiri pesantren tersebut. Namun sekitar tahun 1999-2000 M semenjak adanaya bantuan komputerisasi di Pesantren Miftahul Huda, maka secara berangsur-angsur segala sesuatu yang berkaitan dengan lingkungan pesantren mulai di catat dan didokumentasikan". Adapun kegiatan pembanguan yang dapat didokumentasikan bisa dilihat dari tabel dibawah ini (Huda, 2010):

Tabel 1. Kegiatan Pembangunan Ponpes Miftahul Huda

\begin{tabular}{|c|c|c|}
\hline No & Tahun & Kegiatan Pembanguanan \\
\hline 1 & 2000 & Membangun Koprasi Pesantren atau Mini Market \\
\hline 2 & 2001 & Memperbaharui Asrama putri \\
\hline 3 & $2002-2003$ & $\begin{array}{l}\text { Membanguan Jalur Suci yang menuju ke Mesjid dan ke asrama seluruh } \\
\text { santri putra dan santri putri, serta membereskan banguan yang belum rapi }\end{array}$ \\
\hline 4 & 2004-2005 & $\begin{array}{l}\text { Membangun tambahan ruangan kelas, dan membanguan gedung HAMIDA } \\
\text { atau gedung Himpunan Alumni Miftahul Huda. }\end{array}$ \\
\hline 5 & 2006-2007 & Membanguan sarana pelenggkap, seperti GOR, Lapangan \\
\hline 6 & $2008-2009$ & Membanguan Jalan ke arah selatan tepatnya ke darah Cisitu kidul \\
\hline 7 & 2010 & Melakukan kegiatan pengecoran jalan ke darah Cisitu kidul \\
\hline 8 & 2011 & $\begin{array}{l}\text { Membanguan Asrama untuk dua asrama putri yang jumlah kamarnya } \\
\text { berbeda-beda, minimal jumlah kamarnya } 22 \text { kamar. Pembangunan Yayasan } \\
\text { Asofa }\end{array}$ \\
\hline 9 & 2012 & Pembanguan rumah Dewan Kyai, \\
\hline
\end{tabular}

Sumber : Staf Kepengurusan Pesantren Dalam Bidang Pembangunan.

Ustad Aceng menambahkan "jika penerangan listrik mulai masuk ke Pesantren Miftahul Huda sekitaran tahum 1989 M. Beliau juga menambahkan jika dalam pembangunannya segala sesuatu yang berhubungan dengan dana, maka beliau akan mengajukan permohonan dana kebagian keuangan. Sedangkan untuk masalah bidang pembangunan yang akan dibangun itu sendiri tergantung dari keputusan Dewan Kyai, dan para santri hanya sebagai pelaksana saja. Untuk masalah ukuran para santri tidak mengetahui dengan begitu jelas sehingga sulit untuk menetukan ukuran atau luas bangunan yang sudah ada dan banguanan yang akan dikerjakan, sementara ketika penulis akan mencoba mewawancarai Dewan Kyai yang bersangkutan, penulis tidak bertemu dikarenakan yang bersangkutan sedang berada diluar komplek pesantren. Selain dari segi bangunan, pengetahuan santri akan informasi dari luar lingkungan pesantren juga diperhatikan, hal ini terlihat seperti dengan diadakannya papan informasi atau 
Khazanah Theologia, Vol. 1 No. 1: 7-22

Perjuangan Kh.Choer Affandi Pendiri Pesantren Miftahul Huda Manonjaya

Dian Prayoga

majalah dinding yang memuat segala informasi dari dunia luar, disamping itu terdapat juga warung internet yang bisa digunakan semua santri pada waktu libur belajar".

\section{b. Rekapitulasi Jumlah Santri}

Dalam membahas tentang pondok pesantren, maka salah satu penunjang yang patut diketahui adalah santri. Mahmud dalam Model-Model Pembelajaran di Pesantren (MM, 2006) .Pada prinsipnya sebuah lembaga pendidikan dapat dikatakan sebagai pondok pesantren apa bila didalamnya terdapat sedikitnya lima atau enam unsur, yaitu:

a) Kyai

b) Santri

c) Masjid

d) Pondok atau Asrama

e) Pengajian Kitab Kuning atau Salaf

f) Madrasah

Sedangkan yang disebut santri di Pesantren Miftaul Huda adalah mereka yang sengaja datang dan diserahkan oleh orang tua atau wali untuk belajar dan menetap didalam kompleks pesantren. Untuk itu maka penulis memasukan keberadaan santri di Pesantren Miftahul Huda dalam pembahasan ini guna meningkatkan peranan dari Pondok Pesantren Miftahul Huda sebagai pondok pesantren yang besar di wilayah Tasikmalaya. Sebagai mana diketahui bersama, jika pesantren Miftahul Huda adalah Pesantren Salafiyah, sehingga secara otomatis dalam penataan kegiatan pembelajaran santri Pesantren Miftahul Huda pun mengikuti cara-cara pesantren salafiyah yang telah ada sebelumnya. Dimana dalam pesantren salafiyah santri putra dan santri putri tidak belajar secara bersama dalam satu ruangan secara keseluruhan melainkan belajar ditempat yang berbeda dalam satu komplek lingkungan pesantren tersebut, walaupun tidak jarang ada kalanya santri putra mengajar santri putri, namun kejadian sebaliknya tidak harus terjadi.

Dari hasil wawancara penulis dengan Ajengan Otoh di rumahnya, beliau mengatakan: Jika dalam perkembangannya, Pesantren Miftahul Huda pada awal berdirinya hanya memiliki santri yang cukup sedikit, yaitu kurang lebih dari 300 santri, dimana santri tersebut adalah santri yang dibawa oleh Almarhum K.H. Choer Affandi dari Pesantren Gombongsari di daerah Cisitu Kaler ke pesantren barunya yaitu Pesantren Miftahul Huda.

Sedangkan menurut Irsad (pengurus dibidang kesekertariatan) untuk jumlah santri dari tahun ketahun pada rentang waktu sebelum 2009 an tidaklah tercatat atau didokumentasikan secara teratur, hal ini disebabkan belum adanya komputer sehingga pendataan disimpan dalam buku, yang saat penulis coba untuk bisa melihat buku tersebut ternyata sudah tidak diketahui lagi keberadaanya. Hal ini dikarenakan penataan sistem kesekertariatan yang masih belum berpengalaman dan sistem manajemen yang belum teratur. Namun keseluruhan jumlah santri dapat terpantau sekitaran tahun 2000 sampai sekarang, rekapitulasi jumlah santri yang masuk dan keluar pada tiap tahunnya relatif sama yaitu santri masuk dalam tiap tahunnya kurang lebih mencapai angka 200 santri, dan santri yang keluar setiap tahunnya juga kurang lebih mencapai angka 200 santri. Biasanya santri banyak yang masuk pada bulan Syawal dan pada pertengahan tahun Masehi sekitaran bulan Juni sampai Juli atau tepatnya pada tahun pelajaran baru untuk pendidikan umum.

Dalam proses penerimaan santri, Pesantren Miftahul Huda mempunyai beberapa tahapan, diantaranya sebagai berikut:

a) Peserta datang sendiri atau diserahkan oleh orang tua wali dan mendatangi bidang kesekertariatan; 
b) Mengisi formulir pendaftaran;

c) Mengikuti tes Interview;

d) Setelah dinyatakan diterima, Orang tua mengadakan Ijab dan Qobul atau serah terima calon santri antara orang tua dengan pimpinan atau dewan kyai;

e) Menandatangani kesanggupan untuk mentaati peraturan dan tata tertib pesantren;

f) Membayar uang pertama masuk pesantren;

g) Penetapan asrama, dan Penetuan kelas berdasarkan kemampuan.

Sampai tahun 2011M, santri putra dan santri putri yang berada di pesantren Miftahul Huda tercatat berjumlah 2085 santri. Pada kenyataanya banyak pula santri yang berhenti mengaji di pesantren ini, banyak sekali alasan dari santri untuk keluar dari pesantren tersebut, seperti ada yang menikah, tidak betah, sakit-sakitan dan sebagainya, alasan seperti ini banyak disampaikan oleh santri perempuan , bahkan ada pula santri yang memberanikan diri keluar dengan cara bersembunyi-sembunyi, biasanya hal ini banyak dilakukan santri laki-laki. Kejadian seperti ini jarang sekali diketahui oleh staf kepengurusan pesantren sehingga bila melihat hal ini, jumlah santri secara keseluruhan mencapai 3.500 orang santri putra-putri.

Sistem pendidikan Salafiyah pada umunya tidak mengenal penjenjangan, kurikulum, silabus, dan sistem evaluasi, dimana para santrinya belajar tanpa mengenal batas waktu sehingga terkadang ada santri yang belajar hingga belasan tahun bahkan puluhan tahun. Akan tetapi di Pesantren Salafiyah Miftahul Huda, Almarhum K.H. Choer Affandi telah mencoba sejak lama mengembangkan sistem salafiyah menjadi sistem semi formal, dimana penjenjangan, silabus, kurikulum pembelajaran, dan sistem evaluasi disusun berdasarkan tujuan dan sasaran belajarnya. Jenjang pendidikan di Pesantren Miftahul Huda pada dasarnya dibagi menjadi tiga, yaitu Ibtida, Tsanawi, Mahad Ali, semuanya mempunyai tiga tingkatan, hanya saja pada tingkatan dua dan tiga pada jenjang Ma'had Ali kegiatan santrinya lebih dititik beratkan pada praktek mengajar dan mengurusi organisasi.

Untuk kurikulumnya yang digunakan di Pesantren Miftahul Huda adalah kurikulum fleksibel yang disusun oleh Almarhum K.H. Choer Affandi dan dibantu oleh para anggota dewan kyai. Untuk buku sumber atau bahan pelajaran kepada santri di Pesantren Miftahul Huda diambil dari kitab-kitab klasik (Kitab Kuning) yang disusun oleh para ulama salaf. Menurut Irsad selaku pengurus Kesekertariatan Pesantren Miftahul Huda (2012). Secara garis besar kurikulum pengajaran di Pesantren Miftahul Huda lebih diarahkan pada empat pemahaman seperti dalam tabel berikut ini:

Tabel 2. Kurikulum pesantren dan sumber pembelajaran

\begin{tabular}{|c|c|c|}
\hline No & Tujuan & Nama Kitab \\
\hline 1 & $\begin{array}{l}\text { Pemahaman tentang pengetahuan kebahasaan } \\
\text { dan logika, yaitu bahasa arab yang disebut } \\
\text { Ilmu Alat (Gramer), dan Ilmu Mantiq }\end{array}$ & $\begin{array}{l}\text { Kitab Jurumiah, } \\
\text { kitab Shorof Kailani, Amtsilatut-Tasrif, } \\
\text { Kitab Imriti, } \\
\text { Kitab Alfiyah Ibnu Malik, Kitab } \\
\text { Samarkondi, dan } \\
\text { Kitab Sulamun Nauruq. }\end{array}$ \\
\hline
\end{tabular}


Khazanah Theologia, Vol. 1 No. 1: 7-22

Perjuangan Kh.Choer Affandi Pendiri Pesantren Miftahul Huda Manonjaya Dian Prayoga

\begin{tabular}{|c|c|c|}
\hline & & $\begin{array}{l}\text { Untuk tingkat pemula materi } \\
\text { pembelajaran lebih banyak materi } \\
\text { hapalan }\end{array}$ \\
\hline 2 & $\begin{array}{l}\text { Pemahaman dalam bidang pengetahuan } \\
\text { aqidah yang penekannya pada aspek } \\
\text { penghayatan }\end{array}$ & $\begin{array}{l}\text { Kitab Tidjanudarory, } \\
\text { Kitab Aqidatul 'Awam, } \\
\text { Kitab Khulasoh Ilmu Tauhid, Kitab } \\
\text { Majmu'atul Aqidah, Kitab Sya'bun Iman, } \\
\text { Kitab Goyatul Wusul, dan } \\
\text { Kitab Aqidah Al-Islamiyah }\end{array}$ \\
\hline 3 & $\begin{array}{l}\text { Pemahaman dalam bidang Syari'ah yang } \\
\text { penekannya pada aspek pengamalan ibadah } \\
\text { dan mu'amalah (fiqih) }\end{array}$ & $\begin{array}{l}\text { Kitab Safinah, } \\
\text { Kitab Tawrib, } \\
\text { Kitab Riyadul Badi'ah, } \\
\text { Kitab Lanatuts-Tolobin, } \\
\text { Kitab Fhatul Main, } \\
\text { Kitab Fatul Wahab }\end{array}$ \\
\hline 4 & $\begin{array}{l}\text { Pemahaman dalam bidang Ahlaq dan Tasauf } \\
\text { yang penekannya pada aspek prilaku }\end{array}$ & $\begin{array}{l}\text { Kitab Ahlaq Lilbanin, } \\
\text { Kitab Sulamutaofiq. }\end{array}$ \\
\hline
\end{tabular}

Sumber : Staf Kepengurusan Pesantren Miftahul Huda

Disamping keempat sasaran pokok, diberikan pula pelajaran lain yang memberikan kontribusi terhadap materi pelajaran pokoknya seperti Ilmu Tariqh untuk semua santri, dan ilmu A'rud Qowafy, Ilmu falaq diberikan pada santri yang sudah tinggat Ma'had Ali.

Selain kurikulum inti pengajaran diatas, terdapat pula kegiatan ekstra kulikuler yang meliputi keorganisasian seperti Organisasi asal santri, kegiatan-kegiatan keterampilan, pertukangan, peternakan, pertanian, dan keterampilan semi militer yang diberi Nama RESSANT Miftahul Huda, serta wiraswasta.

Dalam perkembangannya, sistem pembelajaran yang berada di Pesantren Miftahul Huda dari awal sampai sekarang tidak ada perubahan yang signifikan, hal ini dikarenakan sistem pembelajaran yang diterapkan sudah terasa dan bisa dibilang berhasil dalam menerapkan pola pengajaran kepada santri yang datang dari berbagai kalangan dan sosial budaya yang berbeda-beda. Dalam segi kegiatan pembelajaran yang berada di Pesantren Miftaul Huda dapat dilihat dari jadwal kegiatan harian, seperti:

Tabel 3. Siklus Aktivitas Santri

\begin{tabular}{|c|c|c|}
\hline No & Waktu & Kegiatan \\
\hline
\end{tabular}


Khazanah Theologia, Vol. 1 No. 1: 7-22

Perjuangan Kh.Choer Affandi Pendiri Pesantren Miftahul Huda Manonjaya Dian Prayoga

\begin{tabular}{|c|c|c|}
\hline 1 & $03.00-03.30$ & Bangun malam dan persiapan Sholat Tahajud \\
\hline 2 & $03.30-04.30$ & Sholat Tahajud \\
\hline 3 & $04.30-05.00$ & Sholat Subuh berjama'ah \\
\hline 4 & $06.00-06.30$ & Sorogan \\
\hline 5 & $06.30-06.45$ & Sholat Duha bersama \\
\hline 6 & $06.45-07.30$ & Gerakan kebersihan \\
\hline 7 & $07.30-09.30$ & Persiapan masuk kelas \\
\hline 8 & $09.30-10.00$ & Mudzakarah \\
\hline 9 & $10.00-10.15$ & Makan siang \\
\hline 10 & $10.15-11.30$ & Istirahat siang \\
\hline 11 & $11.30-12.00$ & Persiapan Sholat Duhur berjama'ah \\
\hline 12 & $12.00-12.30$ & Sholat Duhur berjama'ah \\
\hline 13 & $12.30-14.00$ & Belajar Ibtida, Tsanawi, Mahad Ali \\
\hline 14 & $14.00-15.00$ & Persiapan Sholat Ashar \\
\hline 15 & $15.00-15.30$ & Sholat Ashar berjama'ah \\
\hline 16 & $15.30-16.00$ & Tarkiban/ belajar menafsirkan \\
\hline 17 & $16.00-17.00$ & Belajar Ibtida, Tsanawi, Mahad Ali \\
\hline 18 & $17.00-17.30$ & Makan sore \\
\hline 19 & $17.30-18.00$ & Persiapan Sholat Magrib \\
\hline 20 & $18.00-18.30$ & Sholat Magrib berjama'ah \\
\hline 21 & $18.30-19.30$ & Kuliah Tafsir Jalalin \\
\hline 22 & $19.30-20.00$ & Sholat Isa berjama'ah \\
\hline 23 & $20.00-21.00$ & Balagan Ibtida, Tsanawi diskusi hukum, Ma'had Ali pengabdian \\
\hline 24 & $21.00-22.00$ & Menghapal bersama \\
\hline 25 & $22.00-03.00$ & Istirahat malam \\
\hline
\end{tabular}


Sumber : kesekertariatan Pesantren Miftahul Huda

Selain hal-hal tersebut diatas, sisi menarik yang ada dalam pesantren Miftahul Huda adalah dengan adanya sistem pengkaderan yang dilakukan oleh pesantren, dimana sistem ini berlaku apabila:

a) Bagi santri yang dianggap paling menonjol dalam bidang pengetahuan dan ahlaq atau tingkah lakunya, serta adanya persetujuan dari keluarga dan santri yang bersangkutan.

b) Izbar, dimana santri yang dianggap paling menonjol dalam bidang pengetahuan dan ahlak atau tingkah lakunya akan dinikahkan dengan kerabat atau bahkan anak dari kelurga pesantren sendiri, atau santri dengan santri lagi.

c) Santri yang dianggap lulus dari tingkatan akhir dan dianggap matang dalam ilmu dan prilakunya, maka mereka ditawari alternatif seperti membuka pesantren baru di tempat yang sangat minim dalam membina keagamaan.

Tujuan dari sistem pengkaderan ini adalah upaya pesantren dalam menyebarkan ajaran agama Islam ke berbagai wilayah dan keberbagai kalangan, sedangkan sistem izbar adalah guna mempertahankan eksistensi dan kualitas pesantren itu sendiri dalam menghadapi perkembangan zaman. K.H. Imam Zarkasyi dalam Rohadi Abdul Fatah “Rekontruksi Pesantren Masa Depan” (2008: 21). Tujuan pendidikan pesantren adalah "kemasyarakatan dan dakwah Islamiyah" artinya pendidikan diarahkan pada kebutuhan masyarakat luas pada umumnya serta kepentingan dakwah Islamiyah pada khususnya.

Selain sistem pengkaderan, di Pesantren Miftahul Huda diadakan pula program pengabdian, dimana program ini berlaku bagi semua santri yang telah menamatkan jenjang Mahad Ali. Pengabdian disini adalah semua santri wajib memberikan segala sesuatu yang mereka miliki baik secara tenaga maupun secara pikiran guna turut serta dalam memajukan pendidikan dan pembangunan Pesantren Miftahul Huda. Adapun lama pengabdian terhadap pesantren tidak diberikan batasan waktu hanya saja para santri berpendapat minimal pengabdian itu selama satu tahun, bahkan ada santri yang melakukan pengabdian selama beberapa tahun.

\section{Potret Kegiatan Santri dan Organisasi Pesantren Miftahul Huda}

Pembahasan mengenai santri, bagaimana sebaiknya menjadi santri dan memberdayakan santri dalam keterpaduan kegiatan intra maupun kegiatan ekstra asrama (pondok pesantren) masih kurang sekali. Padahal santri dan pembinaan santri merupakan komponen yang tidak kalah penting dari komponen-komponen lain pondok pesantren yang saling berhubungan sehingga menjadi sebuah kesatuan sistem. Dalam hal ini penulis sedikit menggambarkan tentang bagaimana potret kegiatan santri baik didalam asrama atau diluar asrama, dan bagaimana santri menyusun agendanya sendiri guna mempersiapkan dalam menyambut masa depannya. Dalam pembahasan ini, maka penulis mencoba menguraikannya dalam dua bagian, yaitu: (1). Kegiatan santri di dalam pesantren atau asrama; (2). Kegiatan santri diluar pesantren.

Menurut Ade Sirojudin (2012), santri Miftahul Huda yang menjabat Ketua Santri. Kegiatan santri di pesantren atau asrama selain belajar secara keseluruhan didalam kelas, mereka dipastikan akan pulang kedalam kamar, di Pesantren Miftahul Huda sendiri kegiatan mereka setelah mengaji di kelas kebanyakan santrinya belajar didalam kamar atau kobong masing-masing yang dikenal dengan sistem Balagan (menemui santri sekamar yang sudah senior guna mempelajari kembail pelajaran yang belum dimengerti). Dari beberapa kamar tersebut ada yang dinamakan asrama, dimana di pesantren ini setiap asrama mempunyai struktur kepengurusan sendiri-sendiri. Adapun kegiatan santri di setiap asramanya dikelola oleh ketua asrama atau ro' is asrama atau lurah asrama sebagai perpanjangan dari pengawasan pengasuh pesantren itu sendiri dalam membina dan mendidik santri. Salah satu kegiatan santri adalah menghapal 
bersama, membersihkan asrama, dan makan bersama. Kepengurusan ini biasanya membuat suatu kegiatan, seperti:

a) Kegiatan harian, mencakup kegiatan balagan, besih-bersih didalam kamar dan halaman;

b) Kegiatan mingguan, mencakup Kegiatan seperti bersih-bersih setiap hari jum'at pagi di seluruh kompleks pesantren, olah raga, serta perlombaan seperti, cerdas cermat, lomba pidato, dan sebagainya. Dan mengkondisikan pengajian untuk Ibu-ibu setiap hari selasa dan pengajian umum setiap malam kamis.

c) Kegiatan bulanan, mencakup kegiatan Ujian Akhir semester dan Ujian Tengah Semester, dan perlombaan seperti pertandingan sepak bola dengan pesantren lain atau pertandingan perasrama. Biasanya setelah diadakan Ujian Akhir Semester selama sepuluh hari dan Ujian Tengah Semester santri diberikan waktu pulang untuk berlibur selama seminggu disamping liburan menjelang Lebaran. Sebagai catatan santri diperbolehkan pulang hanya pada waktu liburan Akhir Semester dan libur menjelang Hari Raya Idul Fitri.

Sedangkan untuk kegiatan santri diluar pesantren untuk Miftahul Huda sendiri bukan berarti santri bebas untuk melakukan kegiatan diluar kompleks pesantren, namun dalam hal ini kegiatan di luar pesantren lebih menitik beratkan pada kegiatan santri diluar pembelajaran mengenai ilmu-ilmu keagamaan. Kegiatan ini mencakup kegiatan membuat atau ikut membantu pembangunan seperti ikut membantu pekerja dalam membangun, membersihkan kolam ikan, memeriksa saluran air, memelihara peternakan, perikanan, dan pertanian. Dalam hal ini santri yang bekerja adalah santri yang sedang ikut piket, maka mereka akan ikut dipekerjakan.

Dari kepengurusan perasrama ini, maka akan kita jumpai keorganisasian seperti ketua asrama, kemanan asrama, sekertaris dan yang lainnya, sehingga dari keorganisasian itu maka muncul pulalah keorganisasian terkecil seperti organisasi atau kepengurusan perkamar.

\section{SIMPULAN}

Latar belakang berdirinya Pesantren Miftahul Huda yang penulis ketahui dari K.H. Abdul Fattah selaku anak almarhum Uwa Ajengan adalah karena wilayah Manonjaya merupakan wilayah yang dianggap berjarak sama dengan Provinsi Jawa Barat. Selain itu, di wilayah Manonjaya terdapat tiga alumni atau mustami yang sering mengikuti pengajian di pesantren yang pertama almarhum dirikan di wilayah Cigugur. Namun sebelum sampai ke tempat yang sekarang menjadi Pesantren Miftahul Huda almarhum mendirikan dahulu pesantren di daerah Cisitu Kaler dengan nama Pesantren Gombongsari akan tetapi sewaktu melakukan perjalanan menuju Mesjid Kaum Manonjaya untuk mengisi pengajian disana, beliau selalu bermimpi ketika beristirahat dan tidur, jika beliau ingin mendapatkan ilmu yang menfaat dan mempunyai pesantren yang besar maka harus mendirikan pesantren di tempat tersebut, begitu kira-kira isi mimpi tersebut. Selain itu pesantren pertama yang beliau dirikan di wilayah Manonjaya terletak di tengah pemukiman masyarakat sehingga memungkinkan beliau kesulitan dalam menerapkan kedisiplinan terhadap santrinya. Perkembangan Pesantren Miftahul Huda dari awal berdirinya pesantren terjadi dengan sangat signifikan, dahulu santrinya hanya sedikit namun dengan keunggulan yang dimiliki pesantren tersebut membuatnya semakin dikenal dan dijadikan tempat bagi masyarakat untuk menuntut ilmu agama. Selain itu dampak Pesantren Miftahul Huda sangat besar pengaruhnya bagi masyarakat setempat, baik dalam bidang ekonomi seperti meningkatnya jumlah pendapatan pedagang di sekitar pesantren, bidang sosial budaya seperti meningkatnya jumlah penduduk desa setempat dan banyaknya ragam bahasa yang dipergunakan santri, hal ini terjadi karena latar belakang santri berasal dari berbagai daerah. selain itu dengan adanya pesantren tersebut membuat pemerintah memperhatikan dengan 
membanguan dan meningkatkan kualitas jalan yang menuju pesantren tersebut atau daerah-daerah sekitaran pesantren itu.

\section{DAFTAR PUSTAKA}

Fatah, R. A. (2005). Rekontruksi Pesantren Masa Depan. Jakarta: PT. Listafariska Putra.

Fattah, A. (2010). Asal Mula Uwa Ajengan Datang Ke Manonjaya. Bandung: CV. Wahana Iptek Bandung.

Fazari BA, M. (1996). Ikhlas Mengabdi, Biografi Uwa Ajengan Manonjaya. Manonjaya: YAMIDA.

Haedari, A. (2004). Panorama Pesantren Dalam Cakrawala Modern. Jakarta: Diva Pustaka.

Huda, R. F. (2010). Kurikulum Pesantren Miftahul Huda. Tasikmalaya: Institut Assofa Miftahul Huda. Madjid, N. (1997). Bilik-bilik Pesantren, sebuah Potret Perjalanan. Jakarta: Paramadina.

MM, M. (2006). Model-model Pembelajaran di Pesantren. Tanggerang: Media Nusantara.

Moleong, L. J. (2011). Metodologi Penelitian Kualitatif, cetakan XXIX. Bandung: PT. Remaja, Rosdakarya.

Rahardjo, M. (2010). Triangulasi dalam penelitian kualitatif.

Raharjo, M. D. (1985). Pergulatan Dunia Pesantren Dari Bawah. Jakarta: P3M.

Sugiyono. (2013). Metode Penelitian Pendidikan Pendekatan Kauntitatif, kualitatif dan R\&D. Bandung: Alfabeta. 